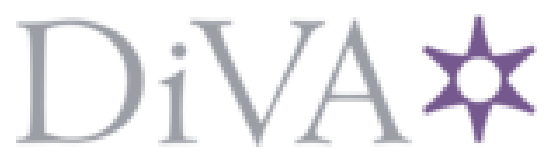

http://www.diva-portal.org

This is the published version of a paper published in Episteme: A journal of individual and social epistemology.

Citation for the original published paper (version of record):

Egeland, J. (2018)

Epistemic Internalism and Testimonial Justification

Episteme: A journal of individual and social epistemology

https://doi.org/10.1017/epi.2018.48

Access to the published version may require subscription.

N.B. When citing this work, cite the original published paper.

Permanent link to this version:

http://urn.kb.se/resolve?urn=urn:nbn:se:su:diva-179032 


\title{
EPISTEMIC INTERNALISM AND TESTIMONIAL JUSTIFICATION
}

\author{
JONATHAN EGELAND
}

Jonathan.egeland.harouny@philosophy.su.se

\begin{abstract}
According to epistemic internalists, facts about justification supervene upon one's internal reasons for believing certain propositions. Epistemic externalists, on the other hand, deny this. More specifically, externalists think that the supervenience base of justification isn't exhausted by one's internal reasons for believing certain propositions. In the last decade, the internalism-externalism debate has made its mark on the epistemology of testimony. The proponent of internalism about the epistemology of testimony claims that a hearer's testimonial justification for believing that $p$ supervenes upon his internal reasons for thinking that the speaker's testimony that $p$ is true. Recently, however, several objections have been raised against this view. In this paper, I present an argument providing intuitive support for internalism about the epistemology of testimony. Moreover, I also defend the argument against three recent objections offered by Stephen Wright in a couple of recent papers. The upshot of my discussion is that external conditions do make an epistemic difference when it comes to our testimonial beliefs, but that they cannot make any difference with respect to their justificatory status - i.e., they are justificationally irrelevant.
\end{abstract}

\section{INTERNALISM AND EXTERNALISM ABOUT TESTIMONIAL JUSTIFICATION}

Epistemic internalists claim that facts about justification depend upon one's internal reasons. The traditional way of unpacking the notion of internal reasons is to say that one's internal reasons are one's a priori accessible reasons - where a priori is used in the narrow or traditional sense that a condition is a priori just in case it doesn't depend on any of the sense modalities. ${ }^{\mathrm{I}}$ Thus, the modes of a priori accessibility include not only reflection and reasoning, but also introspection and other cognitive mechanisms with an experiential aspect. And, in this way, internalists emphasize the epistemic importance of one's subjective point of view on the world. Epistemic externalists, on the other hand, deny this. More specifically, they deny that only internal or a priori accessible reasons can have justificatory relevance. Instead, they think that facts about reliability, factive mental states, or other conditions that are external to one's subjective point of view can make a justificatory difference.

I For a discussion of the distinction between narrow and broad notions of the a priori, see Casullo (2003: Ch. 2). 
The internalism-externalism debate has recently made its mark on the epistemology of testimony. Consider, for example, someone telling you that Sir Arthur Conan Doyle is the author of Sherlock Holmes, or that the New York Public Library has more than 50 million items. A significant number of the beliefs we hold come from assertions like these. ${ }^{2}$ Assertions present propositions that the speaker represents as being true, and that a hearer under the right conditions can get knowledge or justified beliefs from. The epistemology of testimony is about how we should evaluate such beliefs under different conditions. According to the internalist about testimonial justification, the following thesis is true:

TJ Internalism: A hearer's testimonial justification for believing that $p$ supervenes upon his internal reasons for thinking that the speaker's testimony that $p$ is true. ${ }^{3}$

TJ internalists thus think that testimonial justification has its primary source in the hearer, rather than the speaker. Moreover, as formulated above, TJ internalism entails the following thesis about the justificatory status of internal duplicates:

Duplicates: If any two hearers are the same with respect to their internal reasons for thinking that a speaker's testimony that $p$ is true, then they are the same with respect to testimonial justification for believing that $p$.

Externalists about testimonial justification, however, reject TJ internalism, instead claiming that conditions that are external to the hearer's subjective point of view can make a difference with respect to his testimonial justification. ${ }^{4}$

In this paper, I will argue for TJ internalism and defend it against recent objections. First, I will present an argument providing intuitive support for the view that only internal reasons can make a difference with respect to testimonial justification. Having thus motivated TJ internalism, I will defend it against three objections recently offered by Stephen Wright. ${ }^{5}$ The upshot of my discussion will be that externalist conditions do make an epistemic difference when it comes to our testimonial beliefs, but that they cannot make any difference with respect to their justificatory status - i.e., they are justificationally irrelevant.

This is how the paper is structured. Section 2 presents an argument in favor of TJ internalism. Sections 3, 4, and 5 respond to three objections recently offered by Wright. Section 6 comments on Wright's criticism of Jennifer Lackey, arguing that he either must accept TJ internalism or an externalist position similar to Lackey's. Section 7 concludes.

2 I will only focus what Coady (I992) calls natural testimony. Natural testimony, unlike formal testimony which can be found in, for example, the courtroom, "is to be encountered in such everyday circumstances as exhibit the 'social operations of mind': giving someone directions to the post office, reporting what happened in an accident, saying that, yes, you have seen a child answering to that description, telling someone the result of the last race of the last cricket score" (Coady I992: 38 ).

3 Proponents of TJ internalism include Fricker (1994, 2006), Fumerton (2006), Lehrer (2006), and Madison (2016). Moreover, there are different views about what having internal reasons for considering the speaker's testimony true amounts to. Some, like Lyons (I997), Adler (2002), and Shogenji (2006), believe that the reasons must support the general trustworthiness of the testifier, while others, like Fricker (1994, I995), Malmgren (2006), and Lipton (2007), believe that the reasons must support the testifier's trustworthiness in the particular case in question.

4 Proponents of TJ externalism include Lackey (2008), Sosa (20I0), Faulkner (20II), and Wright (20I6a, b).

5 Wright (20I6a, 20I6b) actually offers arguments for externalism about testimonial justification, but for the present purpose his arguments can be formulated as objections to the argument of this text without omitting any of his central points. 


\section{THE ARGUMENT}

I will begin by presenting a scenario that will serve as the basis for an argument for TJ internalism. The scenario considers a pair of epistemic agents that are duplicates with respect to their internal reasons, but that differ with respect to external conditions, such as reliability and truth. And by evaluating the epistemic positions of both agents, the scenario provides the intuitive basis for an inference to the best explanation saying that the character of justification is epistemically internal. The argument's general structure is familiar from the internalism-externalism debate, ${ }^{6}$ but has had less impact on the epistemology of testimony. ${ }^{7}$ The scenario I will consider is as follows.

\section{Trustworthy and Untrustworthy College}

Consider two ten-year-old epistemic agents, Barry and Larry, who are duplicates with respect to their internal reasons. Barry and Larry go to different, but subjectively indistinguishable, boarding schools. Barry goes to Trustworthy College and Larry to Untrustworthy College. Both Trustworthy College and Untrustworthy College are devoted to teaching its students how things really are with respect to traditional core subjects, like history and geography. The professors at the schools try their best to be honest and trustworthy, and they never intend to deceive their students. Moreover, both schools teach its students the same things; which is to say that the propositional content of the professors' testimonies at the two schools are the same. However, the schools are situated in different environments. In the environment in which Trustworthy College is situated, the propositional content of the professors' testimonies almost always turn out to be true. But in the environment in which Untrustworthy College is situated, the propositional content of the professors' testimonies usually turn out to be false. As a consequence, most of Barry's testimonial beliefs are true, whereas most of Larry's testimonial beliefs are false. However, despite the difference in their track records, the professors at the two schools seem to be, from the students' subjective point of view, equally trustworthy; they are all regarded as knowledgeable and wellinformed with respect to their respective areas of expertise.

Now, let's evaluate Barry and Larry's epistemic positions. First, it is clear that there is a difference between them. Whereas Barry's testimonial beliefs are highly reliable and almost all true, Larry's testimonial beliefs are generally unreliable. When Barry forms beliefs based on the testimonies of his professors, his beliefs represent his environment in a truth-conducive manner. But when Larry does the same, his beliefs usually misrepresent his environment. Following a recent trend in epistemology, we can define epistemic entitlement as a condition that (primarily) turns on the reliability or truth-conduciveness of one's doxastic dispositions in one's normal environment. ${ }^{8}$ A natural way of conceptualizing the difference between Barry and Larry's epistemic positions is then to say that Barry's beliefs are entitled, whereas Larry's beliefs either are entitled to a much lower degree or, even worse, not entitled at all.

A second difference between Barry and Larry is that Barry appears to get a lot of knowledge by relying on the testimonies of his professors. The professors at Trustworthy College undoubtedly know a lot about their respective areas of expertise. And the internal reasons Barry has for trusting his professors appear to facilitate

6 The locus classicus being Lehrer and Cohen's (1983) New Evil Demon Problem for reliabilism.

7 A notable exception is Gerken (2013).

8 See, e.g., Burge (2003), Graham (2010), and Gerken (2013). 
transmission of much of this knowledge, via their testimonies, to him. Larry, on the other hand, appears to get very little knowledge by relying on the testimonies of his professors even when what they say actually turns out to be true. The professors at Untrustworthy College are simply too unreliable and insensitive with respect to the facts about their (so-called) areas of expertise. Following Alvin Plantinga (1993), we can define epistemic warrant as the condition(s) that turns true belief into knowledge. 9 Another natural way of conceptualizing the difference between Barry and Larry's epistemic positions is then to say that Barry's beliefs (often) are warranted, whereas Larry's beliefs usually aren't.

However, despite the differences in their epistemic positions, there also seems to be something they have in common that speaks in favor of them. Both Barry and Larry's testimonial beliefs are supported by their internal reasons, and, as a consequence, they appear to be equally justified. After all, as far as the students are concerned, the schools are indistinguishable in all the relevant ways. More specifically, from the students' perspective, the professors at Untrustworthy College are no less trustworthy than the professors at Trustworthy College. And since the apparent trustworthiness of the professors at Trustworthy College seems to justify their students' testimonial beliefs, so does the apparent trustworthiness of the professors at Untrustworthy College seem to justify their students' testimonial beliefs. Indeed, despite the differences in entitlement and warrant, it seems that the justificatory status of Barry and Larry's testimonial beliefs are the same as long as we hold fixed their internal reasons. And the best explanation for why this should be so is that the facts about which propositions one has testimonial justification to believe, and also the degree to which one has testimonial justification to believe them, supervene upon one's internal reasons. ${ }^{1 \circ}$ By abductive reasoning we can therefore conclude that TJ internalism is true.

To further support this argument, consider a similar scenario, but where Barry is transported from Trustworthy College to Untrustworthy College in the middle of the night while he is fast asleep. Unbeknown to himself, when Barry wakes up he finds himself at Untrustworthy College. Moreover, since the two schools are, from the students' point of view, indistinguishable, Barry continues to believe that he is at Trustworthy College; as far as he can tell, there is nothing indicating that he isn't or that his judgment is compromised. However, after a certain amount of time, Untrustworthy College becomes Barry's new normal environment. ${ }^{\text {II }}$ As a result, the new (testimonial) beliefs he forms by relying on the testimonies of his professors are no longer reliable or truth-conducive. Although his new testimonial beliefs appear to be just as true as his earlier ones, most of them are in fact false.

Now, it is quite clear that Barry's new testimonial beliefs, in contrast to his earlier ones, neither are warranted nor entitled (to the same degree); his doxastic dispositions are simply not reliable or sensitive enough with respect to the facts about his new environment. However, his new testimonial beliefs appear to be just as justified as his earlier ones. After

9 Other epistemologists often use warrant as more or less synonymous with justification. However, for the present purpose, it will be useful to keep the notions separate.

Io Internalists take it to be the best explanation because it is the explanation that is most virtuous. For example, it is very simple, and it provides a unified explanation that doesn't only account for the Trustworthy and Untrustworthy College scenario, but also has the power to generalize to other scenarios as well.

I I For more on the notion of one's normal environment, see Gerken (2013: 543-4). 
all, for all that he, or anyone else in his epistemic position, knows, Barry still finds himself at Trustworthy College where the professors are trustworthy. So, once again, it appears that the justificatory status of his testimonial beliefs turns on his internal reasons for believing that what the professors say is true.

In order to see this more clearly, it is enough to point out that Barry in the second scenario has gone from the same position that he was in in the first scenario to the position that Larry was in. Moreover, according to Duplicates, which follows from TJ internalism, all internal duplicates are justificatory duplicates. And since Barry and Larry are internal duplicates, the testimonial beliefs Barry acquires at Untrustworthy College are no less justified than those he acquired at Trustworthy College. TJ Internalism thus appears to provide a simple and natural - indeed, I claim, the best - explanation for the intuitions elicited by the scenarios above.

However, scenarios like these and the arguments they support are not without their critics. In a couple of recent papers, Wright has presented three objections with the purpose of undermining TJ internalism. In the next three sections, I will defend the argument above against them. ${ }^{\mathrm{I} 2}$

\section{THE OBJECTION FROM LACK OF WARRANT}

The first two objections have also been responded to by Brent Madison (2016). For that reason, I will not spend too much time defending my argument against them. However, since I suspect that many externalists about testimonial justification share some of the concerns that Wright's first two objections raise when it comes to TJ internalism, it will be useful to demonstrate why they fail to undermine it.

Plausibly, there exists some sort of necessary connection between justification and knowledge. ${ }^{\mathrm{I} 3}$ According to Wright (2016b: 75), "justification is that which puts someone in a position to know things." Without providing us with any more detail, this presumably means that justification is warrant - i.e., it is whatever condition(s) that is required in order to turn true belief into knowledge. ${ }^{\mathrm{I}}$ Now, with this claim in place, Wright considers a couple of scenarios similar to Trustworthy and Untrustworthy College - one of which is inspired by Frederick Schmitt (I999), and the other being Alvin Goldman's (I976) Fake Barns scenario - and argues, as I also did above, that Barry and Larry's epistemic positions

I 2 Externalists have offered many different responses to the traditional internalist argument that relies on intuitions elicited by Lehrer and Cohen's New Evil Demon Scenario. Although these responses cannot be ignored, they will not be the focus of this paper. The reason for this is twofold. Firstly, they have been responded to in detailed manners before (see, e.g., Littlejohn (20I2: Introduction); and Egeland (Forthcoming)); and secondly, I think the more novel externalists responses, like those of Wright, deserve their own hearing.

I3 However, no philosophical position is immune from dissent. For example, Alston (1989) and Foley (I993) deny that justification is necessary for knowledge.

I 4 Indeed, this is what Wright appears to have in mind. He makes the statement above just after discussing Goldman's (1976) Fake Barns scenario, in which Henry (the person driving in fake barns country) fails to know that the barn he's seeing is real. And, as Wright makes clear, it is "in the same way" that Henry's true belief that the particular barn he's looking at is real fails to constitute knowledge that it also fails to be justified. See Wright (2016b: 75-6). It is for this reason that I think Wright's position plausibly can be reconstructed as saying that justification is Plantinga-warrant. 
differ insofar as it is only Barry's testimonial beliefs that are warranted; that is, it is only he who is in a position to know that the contents of his professors' testimonies are true. And since warrant and justification is the same epistemic property, it therefore follows that only Barry has testimonial justification for his beliefs - despite the fact that Barry and Larry are stipulated to be duplicates with respect to their internal reasons. Hence, since Duplicates, which follows from TJ internalism, is false, so is TJ internalism.

There is, however, a problem with this particular objection. Without providing any motivation for his claim that justification is warrant, the idea that Barry's testimonial beliefs are justified whereas Larry's aren't because only Barry's testimonial beliefs are warranted begs the question against the proponent of TJ internalism. The reason is simply that Wright assumes, without argument, that justification is an externalist notion (i.e., that it is the same as warrant). ${ }^{\text {I5 }}$ But the internalist can of course adopt a different theory of justification, one that doesn't presuppose the necessity of any externalist conditions. Indeed, not only is the internalist free to adopt an alternative view of justification, but there are also strong reasons for why he shouldn't adopt Wright's view. For example, by claiming that justification is warrant, Wright is committed to the view that justified true belief is sufficient for knowledge. However, as Madison (2016: 747) rightfully points out, in the aftermath of Edmund Gettier's (1963) counterexamples, it is clear that the tripartite analysis of knowledge intuitively fails. ${ }^{\mathrm{I} 6}$ We therefore have good reason to reject Wright's claim that justification is warrant, and with it the claim that Barry and Larry differ in terms of testimonial justification too.

\section{THE OBJECTION FROM LACK OF EPISTEMIC VALUE}

However, according to Wright, responding to the objection from lack of warrant in the manner above by denying that justification is warrant reveals another problem with TJ internalism. In the same paper, he tells us that maintaining that Barry and Larry's testimonial beliefs are equally justified despite their difference in warrant "amounts to a serious concession from the internalist, however, since it devalues justification, as internalists conceive of it, detaching it from knowledge" (Wright 20I6b: 73, fn Iо). In other words, Wright thinks that if we deny that justification is warrant, thereby also denying that justification, together with true belief, is sufficient for knowledge, justification appears to lose the epistemic value that we (intuitively) want to accord it. After all, why should we care more about having justified true beliefs than mere true beliefs if the former isn't sufficient for knowledge?

As far as I can see, there is only one reason why one might think that denying Wright's view of justification automatically devalues it, and it is as follows. If you are a monist

I 5 If my reconstruction of Wright position somehow misses its mark, I still think his objection ends up begging the question insofar as it begins from the assumption that "justification is that which puts someone in a position to know," which clearly is an externalist condition.

I6 An obvious reply Wright could make is of course that by stipulating that justification is warrant, the traditional justified true belief analysis of knowledge becomes true since warranted true belief by definition is sufficient for knowledge. However, a worry with this reply is that it doesn't really get at what we want to say that the notion of justification involves. The view under consideration can thus avoid Gettier cases, but only by trading in our traditional concept of justification for a rather uninteresting one. 
about epistemic value, thinking that only knowledge is of intrinsic epistemic importance, then justification might appear to become trivial unless it is sufficient for turning true belief into knowledge. Then, and only then, does justification have instrumental epistemic value as a means to knowledge - the only epistemic property that is valuable in and of itself - or so it might be argued. ${ }^{17}$

However, there are a couple of problems with this kind of objection. First, the internalist isn't committed to the view that the value of epistemic justification is exhausted by the fact that it is a means to knowledge. Alternatively, the internalist can argue that justification either has instrumental value insofar as it is means to satisfying some other (epistemic) property besides knowledge, or that it has value in and of itself. And, moreover, both these views can be found in the literature. Let me give a couple of examples. On the one hand, Declan Smithies (2015) supports the first kind of view and argues that justification has instrumental value insofar as it is means to having beliefs that are stable under rational reflection, and that being able to have beliefs that are stable under rational reflection is the sine qua non of being a person, which is of intrinsic value. On the other hand, Madison (2017) supports the second kind of view and argues, using Keith Lehrer and Stewart Cohen's (1983) New Evil Demon scenario, that we have good reason to believe that justification is valuable in and of itself, for its own sake. So, in other words, there is no reason - at least not any that Wright provides us with - why the internalist should endorse the view that justification only has instrumental value and that this value is exhausted as a means to knowledge.

Second, another problem with the objection from lack of epistemic value is that it assumes that the internalist, by denying that justification is warrant, somehow "detaches" justification from knowledge (in a way that devalues it). But this, however, need not be the case. The proponent of TJ internalism can affirm that justification is connected with knowledge because it is a necessary condition of it (cf. Madison 2016: 747-8). Indeed, not only is this the standard internalist view, ${ }^{\text {I } 8}$ it also doesn't devalue justification. As we saw in the previous paragraph, one can maintain that justification is necessary for knowledge and also claim that it either is of instrumental value as a means to satisfying some other (epistemic) property besides knowledge, or that it is of intrinsic epistemic value. For these two reasons, Wright's second objection therefore fails to undermine TJ internalism as it relies on implausible or unmotivated assumptions. ${ }^{\text {I9 }}$

I7 Questions about the value of being in certain epistemic positions are increasingly being discussed by epistemologists. Here, I simply want to point out the kind of view about the value of justification that Wright's objection appears to presuppose. In my response to this objection, I don't commit myself to any specific position on the issue, but rather point to a couple of views held by others. For more detailed discussions of epistemic value, see Haddock et al. (2009).

I 8 Some, like Poston (n.d.) and McEvoy (2005), claim that internalists are committed to the view that justification, as they understand it, is necessary for knowledge. Although I cannot think of any internalists who would say that you can have knowledge without justification, it doesn't seem like something they're committed to. For example, an internalist can claim that facts about justification supervene upon one's internal reasons, but that whether or not one's beliefs are justified doesn't have any bearing on whether or not they constitute knowledge.

I9 Again, if my reconstruction of Wright's second objection is inaccurate insofar as he doesn't really think that justification is Plantinga-warrant (but rather some other externalist condition), I still think that my response goes through. The internalist can still claim that justification isn't detached from knowledge since it is a necessary condition of it, and that justification either is of instrumental value insofar as it is 


\section{THE OBJECTION FROM CIRCULAR TESTIMONY}

The third objection Wright offers does, at least to my mind, pose a much bigger threat to TJ internalism. In a different paper, Wright (20I6a) argues that there are scenarios involving circular testimony where the internalist is committed to saying that circular testimony, contrary to intuition, generates justification. And since the intuitions elicited by cases of circular testimony (sometimes) speak against TJ internalism, the argument from section 2 fails to provide sufficient support for it.

Testimonial chains can be circular. This happens whenever you have an epistemic agent $a$, who tells something to another agent $b$, who then tells that same (or a relevantly similar) thing to $c$, who then tells that same (or a relevantly similar) thing to ...n, who then tells that same (or a relevantly similar) thing to $a$. Let's call this an instance of circular testimony or, more specifically, an n-sized circular testimonial chain. Now, Wright thinks there are cases of circular testimony that threaten TJ internalism. Consider the following scenario:

\section{CIRCLE}

Agatha looks across the street from her house and comes to believe that the building opposite, which she recognizes as Jesus College, is on fire. She telephones her friend Francesca to tell her the news. Francesca unhesitatingly believes Agatha and then tells this to her friend Anna, though since Anna does not know the college, Francesca describes the building and its location to Anna who in turn unhesitatingly texts this information to Stacy. Stacy is friends with Anna and unhesitatingly believes her. She is also friends with Agatha and realizes that the building in question is Jesus College. Stacy telephones Agatha and tells her that Jesus College is on fire. (Wright 20I6a: 2033)

CIRCLE presents us with an instance of circular testimony - or a 4-sized circular testimonial chain - where Agatha hears from Stacy that Jesus College is on fire. However, according to Wright, since Agatha is responsible for both initiating and terminating the circle, intuitively, she does not receive any testimonial justification for her belief that the college is on fire. Although her belief presumably already is justified by her visual experience, the fact that Stacy tells her that the college is on fire does not further add to the justification of Agatha's belief.

Yet, Wright does not think that all cases of circular testimony fail to generate justification. There must, he thinks, be some other condition that together with the fact that Agatha both initiates and terminates the circle is sufficient for inhibiting the generation of testimonial justification. To indicate what this further condition is, he has us consider the following variation on the first scenario:

\section{CIRCLE*}

Agatha looks across the street from her house and comes to believe that the building opposite, which she recognizes as Jesus College, is on fire. She telephones her friend Francesca to tell her the news. Francesca reflects carefully on the likelihood of Agatha being insincere or mistaken and having done so, comes to believe what Agatha says and then tells this to her friend Anna, though since Anna does not know the college, Francesca describes the building and its location to Anna who in turn considers carefully the possibility of Francesca's testimony being false before

means to satisfying some other (epistemic) property besides knowledge, or that it has value in and of itself. 
texting this information to Stacy. Stacy is friends with Anna and carefully considers the plausibility of Anna's claim before deciding to believe her. She is also friends with Agatha and realizes that the house in question is Jesus College. Stacy telephones Agatha and tells her that Jesus College is on fire. (Wright 20I6a: 2034)

Intuitively, Wright thinks that Agatha does receive justification from Stacy's testimony in CIRCLE* - or at the very least he is open to the possibility. What differentiates the two scenarios and makes it the case that only the former kind of circular testimony fails to generate justification is that the listeners in CIRCLE unhesitatingly believe what they're told. In CIRCLE*, however, the listeners critically reflect on the plausibility of what they hear, which opens for the possibility that their testimonies can add to the justification of Agatha's belief. This is how Wright puts it:

The important difference between the CIRCLE case and the CIRCLE* case is that, in the former, each of the listeners believes what she is told unhesitatingly, whereas in the latter case, each listener reflects carefully on the plausibility of what the speaker says before coming to believe it. In the latter case, it might well be plausible to think that the internalist claim that Agatha's overall justification can be enhanced at the end of the case might well be the correct one. The idea is that, since the statement that Jesus College is on fire seems plausible to multiple individuals who are independently using their critical faculties, this might make them sensitive to more error possibilities and this might make it intuitive that there's additional justification at the end of the chain. Indeed, this may be the case if just one listener responds by using her critical faculties. (Wright 20I6a: 2034)

According to Wright, all cases of circular testimony where the listeners unhesitatingly believe what they are told therefore fail to generate justification. Thus, CIRCLE, but not CIRCLE* $^{*}$, is analogous to the following case where a piece of information uncritically is passed along to an agent:

\section{INSTRUMENTS}

Charlie is attempting to monitor the temperature of some liquid in a glass. He is using two instruments to do this. One gives a reading on a screen and the other gives a reading on a gauge. Both instruments indicate that the temperature of the liquid is $19{ }^{\circ} \mathrm{C}$. Unbeknownst to Charlie, however, the instruments have been set up in such a way that the screen isn't connected directly to the liquid in any way, but just corresponds to what the gauge says. (Wright 2016a: 2036)

In both cases a source of information (Stacy's testimony in Circle and the screen in INSTRUMENTS) is dependent on another source (Agatha's perception in CIRCLE and the gauge in INSTRUMENTS), and uncritically passes the information to an epistemic agent. However, since any case of circular testimony where the listeners (or receivers of information) unhesitatingly (or uncritically) respond to what they are told (or informed about) fails to generate justification, neither Stacy's testimony nor the screen does anything for Agatha or Charlie's belief.

Now, the reason Wright thinks this is problematic for internalism is that if TJ internalism is true, then Agatha's belief in CIRCLE does receive justification from Stacy's testimony. Since Stacy's testimony adds to Agatha's internal reasons for thinking that Jesus College is on fire, it should provide testimonial justification to her belief in that proposition. However, intuitively, it does not. Since the listeners in CIRCLE unhesitatingly 
believe what they're told, Agatha cannot receive justification from Stacy's testimony. ${ }^{20},{ }^{2 I}$

I will respond by denying that the CIRCLE scenario makes it intuitively plausible that Agatha doesn't receive testimonial justification, instead of failing to receive (or increase) some other epistemic property. To see how exactly this response goes, consider the CIRCLE scenario again. If we evaluate Agatha's epistemic position at the end of the scenario, it is clear that there are several ways in which it is the same or worse than it was at the beginning of the scenario. For example, on the one hand, her belief that Jesus College is on fire is no more warranted after listening to Stacy's testimony. If Agatha's visual experience somehow fails to put her in a position to know that the school is on fire, then listening to Stacy's testimony doesn't all of a sudden put her in a position to know that it is. Moreover, on the other hand, her belief that Jesus College is on fire is no more entitled after listening to Stacy's testimony. Quite to the contrary, it might actually make it less entitled; the reason being that beliefs formed on the basis of visual experiences might actually be more reliable than beliefs formed on the basis of visual experiences and circular testimony where the listeners unhesitatingly believe what they hear. ${ }^{22}$ Indeed, there appears to be several ways in which Agatha's epistemic position either stays the same or worsens in CIRCLE.

However, there is also a way in which her epistemic position appears to improve. After all, Stacy's testimony (despite its circular character) does provide Agatha with an (additional) internal reason for believing that Jesus College is on fire. And since there is nothing in the CIRCLE scenario that tells us otherwise, we can account for the presence of this reason by claiming that it adds to Agatha's justification. The proponent of TJ internalism is therefore free to say that the circular testimony in CIRCLE does provide Agatha's belief with testimonial justification, but that it fails to confer any warrant or entitlement upon it. Moreover, the same reply is also available in the INSTRUMENTS scenario. Clearly, the

20 Formulated in this manner, Wright's objection isn't, strictly speaking, sound. The reason is that even though Stacy's testimony adds to Agatha's internal reasons or states, it doesn't follow, according to internalism, that it provides testimonial justification to her belief in the proposition that Jesus College is on fire. For all that internalism tells us, one's internal reasons provide the supervenience base of justification; it does not tell us anything about which internal reasons or states are justificationconferring. So it is open for the internalist to adopt the position that Stacy's testimony doesn't provide Agatha with the right kind of internal reason/state that would be required if her belief was to become more justified. However, since I do think that Stacy's testimony provides Agatha with an internal justification-conferring reason, I won't pursue this line of response any further.

2 I Wright's worry can also be raised as an objection to Duplicates. Agatha, as he sees it, doesn't receive any justification from Stacy's testimony. However, the Agatha in CIRCLE* - let's call her Agatha* does (or at the very least might) receive justification from Stacy's testimony even though they are duplicates with respect to their internal reasons. As Wright points out, this is because the hearers in CIRCLE* critically reflect on the plausibility of what they hear, whereas the hearers in CIRCLE uncritically accept what they hear. Agatha and Agatha* are therefore alike with respect to internal reasons, but not alike with respect to testimonial justification. Hence, since Duplicates, which follows from TJ internalism, is false, so is TJ internalism.

In order for this to be the case the frequency with which beliefs based on visual experiences and circular testimony where the listeners unhesitatingly believe what they're told turn out to be true must be lower than the frequency with which beliefs based on visual experiences turn out to be true. We can easily provide an example where this is the case by imagining a world in which cases of circular testimony where the listeners unhesitatingly believe what they're told usually result in false beliefs (regardless of whether or not those beliefs also are based on visual experiences), whereas beliefs (only) based on visual experiences usually result in true beliefs. 
presence of the screen doesn't confer any warrant or entitlement upon Charlie's belief, even though it does contribute to its justification.

Wright, however, recognizes this response, but thinks that it fails because the intuitions that CIRCLE elicits primarily are about Agatha's epistemic position in general, and not just about justification. This is what he says:

The trouble with this response is that the intuitive support for (I) [that there is no increase in Agatha's overall justification] is stronger than the internalist response allows. It might be correct that there's no specific intuition about justification that supports the claim that Agatha's overall justificatory status isn't enhanced and the end of the CIRCLE case. But the lack of such a specific intuition is of no help to internalist theories. When we are more precise about the intuition that CIRCLE brings about, we see that it is the following:

$(\mathrm{I} *)$ Intuitively, there's no overall improvement in Agatha's epistemic standing in the CIRCLE case ...

The idea is that the intuition in $\left(\mathrm{I}^{*}\right)$ creates trouble for internalist theories because it implies the truth of $(\mathrm{I})$. The idea is that $(\mathrm{I} *)$ is a more general thesis than (I). (Wright 20I6a: 2039)

Of course, Wright is correct when he claims that we do have certain intuitions about Agatha's epistemic position. But $\left(\mathrm{I}^{*}\right)$ is not one of them. Let me elaborate.

First of all, most philosophers agree that Agatha's epistemic position changes when Stacy tells her that Jesus College is on fire; her testimony gives Agatha another internal reason for holding her belief. Wright can of course claim that Stacy's testimony doesn't change Agatha's epistemic position at all. However, Agatha plausibly comes to believe that a friend whom she considers trustworthy thinks that Jesus College is on fire when Stacy tells her that it is. Moreover, denying that this somehow changes Agatha's epistemic position would seem to involve a commitment to the view that Agatha's new belief cannot, in any sense, provide her with another reason to believe that the school is on fire. But this clearly seems to be false. Even though it might not provide her with an external or objective reason to hold that belief, it does provide her with an internal or subjective reason. ${ }^{23}$ So the question is whether or not this internal reason somehow improves her epistemic position. According to Wright, it doesn't. Moreover, this is just an intuition with which everyone should agree, or so he claims. The problem, however, is that, uncontroversially, there are certain internalist conditions that supervene upon one's internal reasons and that do improve one's epistemic position. For example, internalists and externalists generally agree that epistemic blamelessness (or excusability) is an internalist epistemic property. ${ }^{24}, 25$ If, say, you are in a skeptical scenario where most or all of your beliefs about the external world are false, it can still be the case that those beliefs are blameless. If your internal reasons indicate that the world is different from how it really is, then you have an excuse which guarantees that beliefs properly

23 For more on the distinction between objective and subjective reasons for belief, see Sepielli (Forthcoming).

24 But every rule has its exceptions - at least in the philosophical dialectic. For example, Greco (2005) and Srinivasan (2015) claim that there are no interesting internalist properties or norms. However, they face several serious (and, I suspect, insurmountable) objections, the most obvious of which is that it clearly seems, intuitively speaking, that victims of paradigmatic skeptical scenarios do have something epistemically positive going for them. Other, more complex objections have also been developed. See, e.g., Schoenfield (2015).

25 Some internalists think that no sharp distinction can be drawn between justification and blamelessness. See, e.g., Ginet (1975), Chisholm (1989), and Bonjour (1985). 
based on those reasons are blameless - even though they might be radically unreliable. What's more, all else being equal, having blameless beliefs does constitute an epistemic improvement over having blameworthy beliefs. ${ }^{26}$ Indeed, a common strategy used by epistemic externalists to argue that intuitions about Lehrer and Cohen's (I983) New Evil Demon Scenario fail to support internalism is to explain our dispositions to positively evaluate the victim's beliefs by saying that they are blameless but unjustified. ${ }^{27}$ So, in other words, there are internalist epistemic properties that do improve one's epistemic position, blamelessness being a case in point. And given that Stacy's testimony provides Agatha with another internal reason for believing that the school is on fire, Agatha's belief does become blameless to an even greater degree, thereby improving her epistemic position. Hence, $\left(\mathrm{I}^{*}\right)$ is false and the motivation for (I) undermined.

In sum, my response to the objection from circular testimony is that cases like CIRCLE and INSTRUMENTS don't reveal anything special about testimonial justification, rather than some other epistemic property. The internalist, in other words, is free to characterize Agatha as receiving testimonial justification, while failing to receive any entitlement or warrant. Moreover, as we've seen, Wright's counterargument that

I. Agatha's epistemic position doesn't improve in the CIRCLE scenario.

2. If Agatha's epistemic position doesn't improve in the CIRCLE scenario, then she doesn't receive any testimonial justification.

3. Therefore, Agatha's doesn't receive any testimonial justification.

fails since the first premise is false. Intuitively, there are internalist epistemic conditions, like blamelessness, that do improve Agatha's epistemic position. And given that Wright's third objection against the argument from section 2 doesn't succeed, TJ internalism remains well-motivated.

\section{WRIGHT'S “HALFWAY EXTERNALISM”}

Having offered his objection from circular testimony against TJ internalism, Wright ends his (20I6a) paper by trying to differentiate his views from the wholesale externalism of

26 This claim can of course be contested, but only by failing to recognize or somehow contesting the epistemic force of internal or subjective reasons for belief.

27 See, e.g., Williamson (2007), Littlejohn (2009), and Pritchard (2012). A problem with this objection, however, is that it fails to recognize the way in which our intuitions about justification are sensitive to a distinction between beliefs that are false due to perceptual failings and beliefs that are false due to cognitive failings. For example, the victim of the New Evil Demon scenario has beliefs that are false due to perceptual failings (in the sense that his beliefs fail to adequately represent the environment he is situated in), but they still seem justified. On the other hand, if we imagine a similar victim but who also is subject to cognitive failings, like brainwashing or some reason-distorting drug he's been given, that makes him unable to form his beliefs by properly basing them on his perceptual evidence, then they don't seem justified. However, the beliefs of the second victim are clearly just as blameless as those of the first; both of them (let's stipulate) try their best to respect their evidence. Indeed, the difference between their epistemic positions seems to be a difference of justification. But this is not something the proponent of the objection above can acknowledge. As he would have it, both victims have beliefs that are blamelessly unjustified. For more on this problem, see Pryor (200I), Egeland (Forthcoming), and Smithies (Forthcoming). 
Jennifer Lackey. Lackey (2008) argues against $\mathrm{TJ}$ internalism ${ }^{28}$ by presenting a scenario purporting to elicit intuitions to the effect that reliable or truth-conducive testimony is a necessary condition for testimonial justification. ${ }^{29}$ Now, if her argument is sound, then it follows that a listener's internal reasons alone never are sufficient for justifying belief in a speaker's testimony; there is, as she points out, an additional "speakercondition" on testimonial justification (Lackey 2008: I 50).30 This, however, is highly problematic according to Wright. If Lackey is correct, then the internalist story is simply false: having internal reasons are never sufficient for having testimonial justification. But this, he thinks, amounts to radical skepticism when it comes to the epistemic importance of internal reasons. Instead, Wright claims that TJ internalism tells a true story about testimonial justification when it comes to certain cases, but that it isn't the full story:

It [Lackey's externalism] seems to amount to an endorsement of a wholesale scepticism about a listener's reasons in the epistemology of testimony. In the same way that it's one thing to think that inductive evidence in epistemology generally might sometimes fail to justify one's belief, but another thing to think that they never justify one's belief, in the epistemology of testimony

28 More specifically, she argues against reductionism in the epistemology of testimony. However, since it is somewhat controversial how we should draw the reductionism/anti-reductionism distinction, and since internalism clearly also is one of the reductionist views her objection targets, I'll simply, for the purpose of convenience, frame it as an objection against TJ internalism.

The scenario she presents, entitled NESTED SPEAKER, is as follows:

Fred has known Helen for five years and, during this time, he has acquired excellent epistemic reasons for believing her to be a highly reliable source of information on a wide range of topics. For instance, each time she has made a personal or professional recommendation to Fred, her assessment has proven to be accurate; each time she has reported an incident to Fred, her version of the story has been independently confirmed; each time she has recounted historical information, all of the major historical texts and figures have fully supported her account, and so on. Yesterday, Helen told Fred that Pauline, a close friend of hers, is a highly trustworthy person, especially when it comes to information regarding wild birds. Because of this, Fred unhesitatingly believed Pauline earlier today when she told him that albatrosses, not condors (as is widely believed), have the largest wingspan among wild birds. It turns out that while Helen is an epistemically excellent source of information, she was incorrect on this particular occasion: Pauline is, in fact, a highly incompetent and insincere speaker, especially on the topic of wild birds. Moreover, though Pauline is correct in her report about albatrosses, she came to hold this belief merely on the basis of wishful thinking (in order to make her reading of The Rime of the Ancient Mariner more compelling) (Lackey 2008: I49).

Moreover, as she makes clear, the fact that Pauline's testimony is unreliable prevents Fred from receiving any justification from it: "For, even though Helen's testimony provides Fred with excellent positive reasons for accepting the report in question, Pauline is not only a generally unreliable speaker, but she is also reporting a belief which, though true, fails to be reliably produced or appropriately truth-conducive. Because of this, the testimony that Pauline offers to Fred also fails to be reliably produced or appropriately truth-conducive, thereby preventing it from leading to justified or warranted belief for Fred" (Lackey 2008: I49-50).

"What NESTED SPEAKER reveals is that the possession of good positive reasons by a hearer is not sufficient for accepting a speaker's testimony with justification or warrant. Why? Because the possession of positive reasons on behalf of a speaker's report, even when objectively excellent ones, does not necessarily put one in contact with testimony that is reliable. There is, then, a further necessary condition for testimonial justification or warrant, one that requires that a speaker's testimony be reliable or otherwise truth-conducive" (Lackey 2008: I 50). Note how, when it comes to testimonial justification, this shifts the focus away from the hearer and over to the speaker. 
it is one thing to think that a listener's reasons might sometimes fail to justify her belief, or that there must be more to the supervenience base of justification from testimony than these reasons, but quite another thing to think that they never justify a listener's belief.

Lackey's argument ... yields the conclusion that internalist evidence never justifies beliefs based on testimony. The argument based on CIRCLE doesn't yield this conclusion.... This is why the argument here is an argument against the idea that the supervenience claim ... gives a complete account of justification from testimony (Wright 2016a: 2045).

So, in other words, Wright thinks (i) that Lackey's wholesale externalism commits her to skepticism about the epistemic importance of internal reasons, and (ii) that we therefore should adopt some sort of "halfway externalism," according to which a hearer's internal reasons sometimes, but not always, are sufficient for testimonial justification.

However, there are a couple of reasons why these views are problematic. First, Lackey's claim that internal reasons aren't sufficient for testimonial justification doesn't commit her to skepticism about the epistemic importance of such reasons since it can still be the case that they are necessary for testimonial justification or some other epistemic property. For example, she can argue that internal reasons are a necessary, but not sufficient, condition for having testimonially justified beliefs. In that case, internal reasons play a key role in avoiding skepticism. In addition, just because one thinks that a certain set of states (like one's internal reasons) is insufficient for producing certain effects (like a change in one's testimonial justification), it doesn't follow that that set of states is insufficient for producing any relevant effect (like a change in blamelessness). Thus, Wright's criticism of Lackey and her externalist views undermines nothing other than a strawman.

Second, claiming that $\mathrm{TJ}$ internalism is correct insofar as internal reasons sometimes are sufficient for testimonial justification doesn't only undermine Lackey's view, but also appears to undermine Wright's own "halfway externalism." To see why this is so, consider the following passage from the end of his paper:

Unless we claim, however, that [a hearer's internal] reasons cannot justify beliefs tout court, it is hard to see how we can maintain Lackey's claim that they do not justify the listener's belief in the NESTED SPEAKER case, or in any other testimony case ... No such sceptical consequences follow from the argument that I have given here. (Wright 20I6a: 2045)

What Wright here says is that unless we claim that wholesale externalism (which really just is regular externalism) is true, then it is hard to see why the listener's belief in Lackey's scenario, or any other (relevantly similar) scenario, should fail to receive testimonial justification from his internal reasons. ${ }^{3 \mathrm{I}} \mathrm{Or}$, in other words, if we either adopt TJ internalism

When it comes to the NESTED SPEAKER scenario, the internalist might, as usual, stress the fact that from Fred's perspective there is much that speaks in favor of the trustworthiness of Pauline's testimony and virtually nothing that speaks against it. Even if we were to imagine Fred as an ideally rational agent that always responds in the most epistemically reasonable manner to the reasons he has, we are still disposed to say that Fred should believe what Pauline says. Lackey, moreover, appears to offer two responses - one quite modest and the other rather bold. According to the modest objection, the internalist is right to claim that Fred's belief is testimonially justified, but that it fails to satisfy other (externalist) epistemic properties like warrant and knowledge (Lackey 2008: I 50, fn II). This objection simply concedes that the internalist 
or Wright's own "halfway externalism," then none of the scenarios we can come up with will appear to undermine the view that the listener's internal reasons in that scenario are sufficient for testimonial justification. However, if there are no such cases - i.e., no counterexamples - then not only does that undermine Wright's own objections against the internalist, it also seems to constitute an argument in favor of TJ internalism. Let me be more precise.

First, if there are no counterexamples to TJ internalism, then neither his scenario in the (20I6b) paper nor the CIRCLE scenario can provide the intuitive basis for an argument against it. And, as we've seen above, neither of those scenarios appears to provide such a basis (or so I have argued). Second, if TJ internalism tells a true story about the determinants of testimonial justification, and there aren't any counterexamples, then we have good reason to believe that it also is the whole story. The different (internalist or externalist) theories of justification on the market all rely, for their support, on intuitions elicited by various scenarios. Moreover, if only one of these theories - namely, TJ internalism plausibly is able to account for all of these intuitions, then, unless there are other theoretical considerations that weigh heavier than the intuitions and that count against it, that theory remains well-motivated. For these reasons, I conclude that Wright's "halfway externalism" doesn't constitute a theoretically viable position, but rather must collapse into wholesale externalism or internalism about testimonial justification.

\section{CONCLUSION}

Internalists about the epistemology of testimony claim that a hearer's testimonial justification supervenes upon his internal reasons for believing that what the speaker says is true. This claim, which I've called TJ internalism, is not without its critics. In this paper, I have argued in favor of $\mathrm{TJ}$ internalism and responded to three recent objections raised by Wright. The upshot of my discussion is that TJ internalism remains as plausible as ever: testimonial justification does supervene upon one's internal reasons. However, the externalist is right to claim that not all epistemic properties are internal. As we have seen, epistemic agents who are duplicates with respect to their internal reasons often do differ with respect to properties like warrant or entitlement. Yet, although this difference often is of great epistemic importance, it does not undermine internalism in the epistemology of testimony.

Moreover, I've also suggested that one shouldn't try to balance between internalism and externalism about testimonial justification: the ground in-between the positions is simply too narrow (or perhaps not there at all). For simplicity's sake, we should expect the set of internal reasons to either be a sufficient supervenience base for testimonial justification or not, rather than believing its character to be multiform and changing on a case by case basis. ${ }^{2}$

is victorious. The bold objection, on the other hand, says that both internalists and externalists are committed to the view that justification is reliable or truth-conducive, and that Fred's belief therefore will be unjustified on both kinds of view (Lackey 2008: I 5 I-2). This objection, however, clearly misrepresents the internalist position (which need not impose a reliability condition on justification), and thus ultimately fails to engage with the internalist response to NESTED SPEAKER. 


\section{REFERENCES}

Adler, J. 2002. Belief's Own Ethics. Cambridge, MA: MIT Press.

Alston, W. P. I989. Epistemic Justification: Essays in the Theory of Knowledge. Ithaca, NY: Cornell University Press.

Bonjour, L. 1985 . The Structure of Empirical Knowledge. Cambridge, MA: Harvard University Press.

Burge, T. 2003. 'Content Preservation.' Philosophical Review, I03: 457-488.

Casullo, P. 2003. 'A Priori Justification.' New York, NY: Oxford University Press.

Chisholm, R. 1989. Theory of Knowledge. Englewood Cliffs, NJ: Prentice-Hall.

Coady, C. A. J. I992. Testimony: A Philosophical Study. Oxford: Clarendon Press.

Egeland, J. Forthcoming. 'The Demon That Makes Us Go Mental: Mentalism Defended.' Philosophical Studies, I-I8.

Faulkner, P. 20II. Knowledge On Trust. Oxford: Oxford University Press.

Foley, R. 1993. Working Without a Net: A Study of Egocentric Epistemology. New York, NY: Oxford University Press.

Fricker, E. 1994. 'Against Gullibility.' In B. Matilal and A. Chakrabarti (eds), Knowing From Words, pp. I25-6I. Dordrecht: Kluwer.

— 1995. 'Critical Notice: Telling and Trusting: Reductionism and Anti-Reductionism in the Epistemology of Testimony.' Mind, I04(4I4): 393-4I I.

— 2006. 'Testimony and Epistemic Autonomy.' In J. Lackey and E. Sosa (eds), The Epistemology of Testimony, pp. 225-50. Oxford: Oxford University Press.

Fumerton, R. 2006. 'The Epistemic Role of Testimony: Internalist and Externalist Perspectives.' In J. Lackey and E. Sosa (eds), The Epistemology of Testimony, pp. 77-92. Oxford: Oxford University Press.

Gerken, M. 20I3. 'Internalism and Externalism in the Epistemology of Testimony.' Philosophy and Phenomenological Research, 87(3): 532-57.

Gettier, E. L. I963. 'Is Justified True Belief Knowledge?' Analysis, 23(6): I 2 I-3.

Ginet, K. 1975. Knowledge, Perception, and Memory. Dordrecht: D. Reidel.

Goldman, A. 1976. 'Discrimination and Perceptual Knowledge.' Journal of Philosophy, 73: 77 I-9I.

Graham, P. 20I0. 'Testimonial Entitlement and the Function of Comprehension.' In A. Haddock, A. Millar and D. Pritchard (eds), Social Epistemology, pp. I48-I74. Oxford University Press.

Greco, J. 2005. 'Justification is Not Internal.' In M. Steup and E. Sosa (eds), Contemporary Debates in Epistemology, pp. 257-69. Oxford: Blackwell.

Haddock A., Millar A. and Pritchard D. H. (eds) 2009. Epistemic Value. Oxford University Press.

Lackey, J. 2008. Learning from Words: Testimony as a Source of Knowledge. Oxford: Oxford University Press.

Lehrer, K. 2006. 'Testimony and Trustworthiness.' In J. Lackey and E. Sosa (eds), The Epistemology of Testimony, pp. I45-59. Oxford: Oxford University Press.

— and Cohen, S. I983. 'Justification, Truth, and Coherence.' Synthese, 55(2): I9I-207.

Lipton, P. 2007. 'Alien Abduction: Inference to the Best Explanation and the Management of Testimony.' Episteme, 4: 238-5I.

Littlejohn, C. 2009. 'The Externalist's Demon.' Canadian Journal of Philosophy, 39(3): 399-434.

- 20I2. Justification and the Truth-Connection. Cambridge: Cambridge University Press.

Lyons, J. I997. 'Testimony, Induction and Folk Psychology.' Australasian Journal of Philosophy, 75 : I $63-78$.

Madison, B. 20I6. 'Internalism in the Epistemology of Testimony Redux.' Erkenntnis, $8 \mathrm{I}(4)$ : $74 \mathrm{I}-55$.

— 20I7. 'Epistemic Value and the New Evil Demon.' Pacific Philosophical Quarterly, 98(I): 89-107.

Malmgren, A.-S. 2006. 'Is There A Priori Knowledge by Testimony?' Philosophical Review, I I 5: I99-24I.

32 Work on this article has received funding from the European Union's Horizon 2020 Research and Innovation programme under Grant Agreement no. 6754I 5 . 
McEvoy, M. 2005. 'The Internalist Counterexample to Reliabilism.' Journal of Southwestern Philosophical Society, 2I(I): I78-87.

Plantinga, A. I993. Warrant: The Current Debate. Oxford: Oxford University Press.

Poston, T. n.d. 'Internalism and Externalism in Epistemology.' Internet Encyclopedia of Philosophy. https://www.iep.utm.edu/int-ext/.

Pritchard, D. 20I2. Epistemological Disjunctivism. Oxford: Oxford University Press.

Pryor, J. 200I. 'Highlights of Recent Epistemology.' British Journal for the Philosophy of Science, 52(I): 95-I24.

Schmitt, F. 1999. 'Social Epistemology.' In J. Greco and E. Sosa (eds), The Blackwell Guide to Epistemology, pp. 354-82. Oxford: Blackwell.

Schoenfield, M. 20I 5. 'Internalism Without Luminosity.' Philosophical Issues, 25(I): 252-72.

Sepielli, A. Forthcoming. 'Subjective and Objective Reasons.' In D. Star (ed.), Oxford Handbook on Reasons and Normativity. Oxford: Oxford University Press.

Shogenji, T. 2006. 'A Defense of Reductionism About Testimonial Justification of Beliefs.' Noûs, 40: $33 \mathrm{I}-46$.

Smithies, D. 2015. 'Why Justification Matters.' In D. Henderson and J. Greco (eds), Epistemic Evaluation: Purposeful Epistemology, pp. 224-44. Oxford: Oxford University Press.

Forthcoming. The Epistemic Role of Consciousness. Oxford: Oxford University Press.

Sosa, E. 2010. Knowing Full Well. Princeton, NJ: Princeton University Press.

Srinivasan, A. 20I 5. 'Normativity Without Cartesian Privilege.' Philosophical Issues, $25(\mathrm{I})$ : 273-99.

Williamson, T. 2007. 'On Being Justified in One's Head.' In M. Timmons, J. Greco and A. Mele (eds), Rationality and the Good: Critical Essays on the Ethics and Epistemology of Robert Audi, pp. 106-22. Oxford: Oxford University Press.

Wright, S. 20I6a. 'Circular Testimony.' Philosophical Studies, I73(8): 2029-48.

— 20I6b. 'Internalism and the Epistemology of Testimony.' Erkenntnis, 8I(I): 69-86.

JONATHAN Egeland is a Ph.D. candidate in philosophy at Stockholm University. His research interests are primarily focused on epistemology, philosophy of mind, Igth century German philosophy, and certain issues in the philosophy of science. He currently, works for the Diaphora project - a European research and training network for collaborative research on the nature of philosophical problems, their resilience, the sources of persistent divergence of expert opinion about them, and their relation to conflicts in the practical sphere. 